\title{
PREKINIO KREDITAVIMO POKYČIAI ES ŠALIŲ TARPTAUTINĖJE PREKYBOJE
}

\author{
Jūratė Pridotkienè \\ Kauno technologijos universitetas, Lietuva, jurate.pridotkiene@ktu.lt \\ cross $^{\text {ref }}$ http://dx.doi.org/10.5755/j01.em.17.2.2181
}

\begin{abstract}
World economic decline of 2008-2009 negatively affected volume of EU and world international trade. Since 2010 the volume of international trade is rising, though the decline has confirmed the significance of trade credit to development and prosperity of international trade. Exporters, providing their customers with trade credits, take the role of banks and, bearing all the risk, give financing to importers. The paper discusses motives that induce exporters to become financial intermediaries and benefit for both exporters and importers of such financial relations. Also changes between 2010 and 2007 in some EU countries' export and import volume and changes in trade credits volume are analysed. The aim the paper is to show benefits of trade credits and changes in the trade crediting volume of some EU countries' international trade. Methods of comparative analysis and statistical data analysis are used.

Keywords: export, trade credit.

JEL Classification: F14, F18.
\end{abstract}

\section{Ivadas}

Prekinis kreditas yra neatsiejama tarptautinès prekybos dalis. Prekinis kreditas vaidina reikšmini vaidmeni, kaip tarptautinès prekybos finansavimo priemonè. Jis taip pat ir gali būti traktuojamas kaip pinigu pasiūlos ekonomikoje komponentas. Ypatingai tarptautinio prekinio kredito reikšmė sustiprëjo 2008-2009 m. pasaulinès ekonomikos nuosmukio metu, kai iš vienos pusés, prekinio kredito gavejams jis tapo vos ne pagrindine tarptautinès prekybos finansavimo priemone, o iš kitos pusės - prekinio kredito teikejjams stipriai rizikuojant dèl pirkèjų patikimumo ir ekonominès situacijos neapibrèžtumo.

Be abejo, tarptautinio prekinio kredito teikejjai susiduria su didesne rizika, nes veikia daugiau rizikos veiksnių, juos sudètingiau sekti ir kontroliuoti. Suteikiant tarptautini prekini kredita, pasireiškia tiek pirkëjo nemokumo rizika, tiek išorine šalies rizika (Pridotkiene \& Dapkus, 2011). Pats rizikos vertinimas šiuo atveju tampa sudètingas ne tik dèl tinkamų rizikos veiksniu parinkimo, bet ir dèl optimalaus jų kiekio nustatymo: per didelè rizikos veiksnių gausa lemia iškreiptą rizikos matą (Mileris \& Boguslauskas, 2010.

Prekinio kredito svarbą tarptautiniu prekybos santykiu plètrai atspindi ir tai, jog jo panaudojimas suteikia eksportuotojui, o tuo pačiu ir ekonomikai didesni konkurencingumą užsienio rinkose. Kiekviena šalis, taip pat ir Lietuva, siekia kuo didesnio eksporto konkurencingumo pasaulinėje rinkoje, tam turi būti sudarytos palankios salygos tiek mikro, tiek makro lygyje (Saboniene, 2009; Bruneckiene \& Paltanaviciene, 2011).

Tarptautinio valiutos fondo ekspertai teigia, kad pasaulio ekonomika vis dar nera atsigavusi ir tolygiai auganti, o atskiriems regionams, tarp ju ir ES, išlieka pakartotinio nuosmukio grèsmé ir ekonominè suirute (International Monetary Fund, 2012). Tokiomis neapibrezžtomis ir nepalankiomis sąlygomis eksportuotojai vis tiek yra priversti rizikuoti savo finansinèmis lěšomis ir teikti prekini kreditą bei pačios tikètis ji gauti iš savo tiekejju , jeigu nori išgyventi aštrios tarptautinès konkurencijos sąlygomis. Todèl prekinio kredito, kaip tarptautinès prekybos finansavimo priemonès svarba tarptautinei prekybai yra akivaizdi, tačiau besikeičiančios ekonominès sąlygos keičia ir eksportuotojų bei importuotojų kreditinius santykius.

Straipsnio tikslas - nustatyti prekinio kredito teikiamą naudą ir prekinio kreditavimo apimčiu pokyčius ES šaliu tarptautinès prekybos santykiuose. Tikslui pasiekti naudojami mokslinès literatūros palyginamoji analizė bei statistinè duomenų analizè.

\section{Prekinis kreditas: motyvai ir nauda}

Prekini kreditą - taip pat ir tarptautini - galima traktuoti kaip tiekèjo trumpalaikę (dažniausiai) paskola pirkejjui, kurią galima prilyginti banko suteikiamai trumpalaikei paskolai, todėl prekinio kredito sukeliamą riziką bei rizikos veiksnius būtų galima analizuoti remiantis finansinèms institucijoms pritaikytais modeliais. Kita vertus, reikia atsižvelgti $i$ tai, kad kreditą suteikia ne finansinè institucija, o prekių tiekèjas, pats kreditas suteikiamas taip pat ne bet kokiam verslo subjektui, bet tik tam pirkejjui, kuris perka prekes iš tiekejo.

S.Y.Paul (2007) artimas savo nuomone tokiam požiūriui, teigdamas, kad prekini kreditą suteikia nefinansinès firmos, kurių pagrindinis tikslas yra parduoti savo prekes pirkèjams, o ne suteikti jiems 
finansinius išteklius; prekinis kreditas traktuojamas kaip apmokèjimo už prekes atidèjimas iki tam tikros datos ateityje. Šiuo atveju nutolstama nuo prekinio kredito, kaip banko paskolos, sąvokos.

Tarptautini prekini kredita galima traktuoti remiantis J.Pridotkienės ir G.Snieškienès (2011) pateikta sąvoka: tarptautinis prekinis kreditas - tai nefinansinių paslaugų imonès prekių pardavimas užsienio prekybos partneriui, kai už parduodamas prekes atsiskaitoma po tam tikro iš anksto sutarto laikotarpio mainais tikintis tam tikros materialios ir nematerialios naudos. Šioje sąvokoje išryškejja ir esminis prekinio kredito skirtumas nuo banko paskolos, t.y. išskiriama ne tik materiali nauda kredito teikejjui (kas būdinga bankams), bet ir nemateriali nauda (būdinga prekinio kredito teikèjams).

Materiali eksportuotojo gaunama nauda už prekinio kredito suteikimą čia suprantama kaip nustatyto dydžio palūkanos, kurias sumoka pirkèjas už teisę naudotis kreditu. Kaip jau minèta, tai būdinga tiek bankų, tiek kitų kreditorių (pavyzdžiui, pardavejjo) suteikiamiems kreditams. Materiali eksportuotojo gaunama nauda už prekini kreditą paprastai atsispindi eksportuojamų gaminių kainose, t.y. prekinio kredito palūkanos tampa kainos dalimi. Ši nauda yra pardavejo uždarbis už patiriamą riziką.

Pardavejjo neuždirbtos palūkanos, atsisakius kitos galimos investavimo formos (tai yra ne i prekini kredita), tolygios prekinio kredito suteikimo alternatyviniams kaštams. Palyginus prekinio kredito alternatyvinius kaštus su banko indèlio ar kai kurių (mažo rizikingumo) vertybiniu popieriu palūkanomis, teigiama, kad prekinio kredito atnešama nauda pardavèjui yra didesnè (priimant sąlygą, kad kreditas grąžinamas visas ir laiku). Bet koks palankus įmonès nusiteikimas investuoti i pirkejją, suteikiant jam prekini kreditą ir atsisakant kito alternatyvaus investavimo būdo, vadinamas finansiniu motyvu (Summers, Wilson; 2003). Iš importuotojo poziciju finansinis motyvas pasireiškia priejjimu prie papildomo finansavimo šaltinio, kas itin aktualu smulkiosioms i̇monèms. Dažnai prekinis kreditas pakeičia poreiki finansuotis iš bankų.

Investavimo i pirkejjų kreditavimą pelningumas kai kurių autorių teigimu gali siekti net iki 45 proc. metiniu palūkanų(Berlin, 2003). Nepaisant to, prekinis kreditas visuomet buvo vienas iš papildomu tarptautinès prekybos finansavimo šaltinių, aktualus tiek mažoms išmonėms, kurių prièjimas prie išorinio finansavimo šaltiniu yra ribotas, tiek ir didelėms tarptautinès prekybos i̇monèms.

Kita vertus, pasikeitusi pasaulio ekonominè situacija pakeite ir tarptautinio prekinio kredito kaštus: išlikusiems bankams itin sugriežtinus kreditavimo politika, dauguma tarptautinių prekinių kreditų tapo netgi pigesni už bankų kreditus, ypač stambioms imonèms-pirkèjoms, kurios turi daugiau galios derantis dèl prekybos sąlygu (Giannetti, Burkart, Ellingsen, 2011). Taigi, papildomas finansavimo šaltinis tapo vienu iš pagrindinių tarptautinès prekybos finansavimo šaltinių.

Tarptautinio prekinio kredito teikiamą nematerialią naudą galima apibūdinti kaip santykių pastovumą tarp pirkejjo ir pardavejjo. Pirkejjas iš galimų tiekejju, siūlančių prekių analogus kainos ir kokybès atžvilgiu, rinksis tą, kuris pasiūlys pirkejui palankesni sandèrí; analizuojamu atveju pirkejjui bus patrauklesnis tas pardavejjas, kuris pasiūlys prekini kreditą (Banham, 2000). Pirkèjo palankumas prekini kreditą suteikusiam pardavejui ir bus nemateriali kredito nauda. Kitaip tariant, kreditorius "nusiperka" pirkèjo palankuma. Pirkejjo palankumą galima traktuoti kaip moralini isipareigojimą ir toliau bendrauti su kreditan pardavusiu tiekeju. Tai yra taip vadinamas konkurencingumo motyvas.

Verta pastebèti, kad kreditorius rizikuoja prekinio kredito suteikimo alternatyviniais kaštais, t.y. investicija į užsienio pirkëją, ne tik todèl, kad pirkèjas gali tapti nemokus ir neatsiskaityti su pardavèju, bet ir todèl, jog pirkèjas turi tik moralini issipareigojimą išlaikyti nuolatinius santykius su pardavèju. Pasikeitus išorinėms sąlygoms ar pirkèjo poreikiams, prekini kreditą suteikusio pardavèjo investicija i̇ užsienio pirkèją gali ir nepasiteisinti.

Remiantis sandorio kaštu motyvu, pardavëjas, suteikdamas prekini kreditą, turi palyginamaji pranašumą prieš kitą prekybos finansuotoją, pavyzdžiui, banką ar kitą panašią finansinę instituciją, nes pastarieji turi mažiau informacijos apie pirkejją, o stebejjimo kaštai yra pakankamai dideli (Summers, Wilson, 2003). Teigiama, kad pardavejjas turi galimybę surinkti informaciją apie pirkejjo finansinę situaciją, pasinaudodamas pačiu pardavimo procesu, taip pat geriau išmano apie rinką apskritai bei kitus tos rinkos dalyvius, ypač tai aktualu bendraujant su užsienio pirkëjais. Pardavejjas taip pat nesiekia pasipelnyti tik finansavimo aspektu, o greičiau tikisi pelno iš sėkmingo sandorio, t.y. prekių pardavimo ir finansavimo kombinacijos.

N.S.Cheng ir R.Pike (2003) išskiria informacijos asimetrijos motyva. Informacijos asimetrijos motyvas apima du aspektus. Pirma, pardavejjas nèra tikras, ar pirkèjas tikrai ketina sumokèti sutartu laiku. Pardavejjas, pasiūlydamas pirkèjui dvi apmokèjimo sąlygas (sumokant anksčiau nei maksimalus kredito terminas ir gaunat nuolaidą arba sumokant pasibaigus sutartam kredito terminui), gali pasitikrinti naujo 
pirkejjo nemokumo riziką. Autorių teigimu, pirkejjai atskleidžia menkas savo verslo kreditavimo galimybes, jeigu nepasirenka greičiau apmoketi prekini kreditą su nuolaida, vietoj to pasirinkdami apmokèti kreditą pasibaigus sutartam terminui ir pilna suma.

Vis tik galima ginčytis, kad toks požiūris klaidingas dėl keleto priežasčių. Giannetti ir kt. (2011) teigimu, tik stambieji tarptautiniai pirkèjai gauna geresnes prekinio kredito sąlygas, t.y., joms taikoma didesnis nuolaidos procentas už ankstesni apmokèjima, tuo tarpu mažesniems pirkèjams tokios privilegijos nèra. Taip pat ekonominiu požiūriu, kiekvienam rinkos dalyviui tas pats pinigu kiekis šiandien yra vertingesnis nei rytoj. Todèl ir pirkejjui gali būti naudingiau neskubėti sumokèti anksčiau sutarto laiko, tarkim jeigu pats pirkejjas yra ne tik prekinio kredito gavejjas, bet ir teikejjas savo tolimesniems pirkèjams. Tokia pirkejo pozicija naudinga ir tuomet, jeigu pardavejas veikia konkurencinejje rinkoje ir kainas nustato remdamasis ne kaštų, o konkurentu kainomis, o prekini kreditą naudoja tik marketingo tikslais, t.y. prekinio kredito kaštus dengia savo pelnu.

Kitas informacijos asimetrijos motyvo aspektas susijęs su informacijos stoka apie produkto kokybę, kai pardavejjas yra geriau informuotas apie parduodamu prekių kokybę nei pirkèjas. Šiuo atveju prekinio kredito terminas suteikia pirkèjui galimybę îvertinti issigytų prekių kokybę. Vèlgi, tarptautinèje prekyboje, kai pirkèją ir pardavèja skiria ne tik geografiniai, bet ir kultūriniai barjerai, šis aspektas sẻkmingam sandoriui tampa itin svarbus. Moksliniai tyrimai rodo, kad imonès, kurių prekių kokybè turi gerą reputaciją, taiko trumpesnius prekinio kredito terminus, nei naujos imonès, kurios, taikydamos ilgesnius prekinio kredito terminus, leidžia pirkèjui geriau susipažinti su nupirktomis prekėmis (Ng, Smith, Smith, 1999). Remiantis šiuo požiūriu, galima teigti, kad pardavèjas siekia užsitarnauti pirkejjo pasitikejjimą, palankumą, todèl šis informacijos asimetrijos motyvas dubliuojasi su konkurencingumo motyvu.

Aptarti prekinio kredito teikimo motyvai paaiškina, kodèl pardavejjas sutinka leistis i kreditinius santykius su pirkejju, nes prekinis kreditas neatsiejamas nuo tam tikros rizikos: esminis prekinio kredito požymis - atsiskaitymas už prekes po tam tikro laiko, nors prekių nuosavybės teisės pirkejjui atitenka iš karto gavus prekes ar paslaugas. Kol pardavejjas neatgavo suteikto pirkèjui kredito, iškyla prekinio kredito rizika. Nepaisant rizikos, prekinis kreditas buvo ir bus svarbi tarptautinès prekybos santykių dalis.

\section{Prekinio kreditavimo apimčių pokyčiai ES šalyse}

Europos Sajunga yra didžiausia pasaulio ekonomikos prekybos dalyvė, jos importo ir eksporto apimtys siekia 20 proc. visos pasaulinės prekybos (European Commission, 2012). Vis tik, pasaulinè krizė paliko ryškiu pokyčių ES tarptautinėje prekyboje. Palyginus $2010 \mathrm{~m}$. eksporto ir importo apimčiu pokyčius su 2007 m. apimtimis, pastebima, kad Suomijos ir Maltos eksporto apimčiu procentinis pokytis buvo labiausiai neigiamas, eksporto sumažejimas atitinkamai sieké 19,5 ir 15,3 procento (1 pav.). Tuo pačiu laikotarpiu didžiausias eksporto apimčiu pokytis buvo Lietuvoje, Latvijoje, Lenkijoje ir Bulgarijoje, ten eksportas 2010 m., palyginti su 2007 m., padidejo atitinkamai 25,1 proc., 18,6 proc., 17,8 proc. ir 15,4 proc.

Didžiausi neigiami importo pokyčiai fiksuojami Airijoje, Latvijoje, Ispanijoje ir Graikijoje (atitinkamai 25,7 proc., 21,1 proc., 16,5 proc. ir 16,1 proc.), o labiausiai importas išaugo Lenkijoje, Slovakijoje ir Nyderlanduose (atitinkamai 11,1 proc., 11 proc. ir 8,4 proc.).

Didžiausias atotrūkis tarp eksporto ir importo apimčiu pokyčiu pastebimas Latvijoje, Bulgarijoje, Lietuvoje, Airijoje ir Ispanijoje. Latvijoje, Bulgarijoje ir Lietuvoje eksporto apimtys padidejo, o importo sumažějo, tuo tarpu Airijoje ir Ispanijoje mažejo tiek eksportas, tiek importas, tačiau importo sumažèjimas buvo ženklesnis. Kitose šalyse tiek eksporto, tiek importo kitimo tendencijos išliko panašios. Analizuojamu šalių bendra eksporto ir importo apyvarta 2010 m., palyginus su 2007 m., sumažéjo atitinkamai 1 ir 1,6 procento.

Kaip rodo atlikta tarptautinės prekybos apimčiu pokyčiu analizė, dauguma ES šalių mažèjo importo srautas, tuo pačiu ir importo sandorių. Eksporto apimtys didèjo tik nedideliame skaičiuje valstybių, iš kuriu dvi - Lietuva ir Latvija - yra nedidelès ekonomikos šalys, taigi jų eksporto sandorių skaičius bendram ES eksporto sandorių skaičiui didelès įtakos nedaro. 


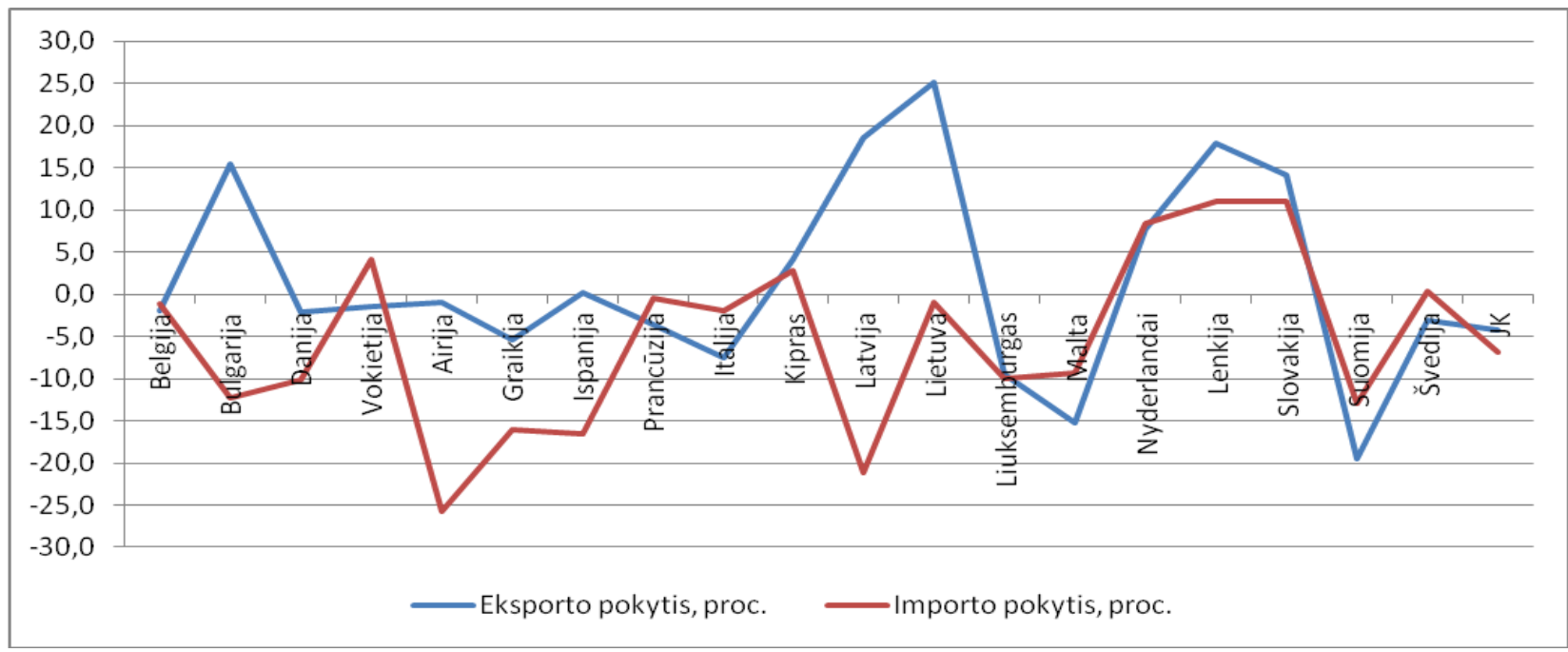

1 pav. Kai kurių ES šalių eksporto ir importo apimčiu pokytis 2010 m. lyginant su 2007 m., proc.

(Eurostat, 2012)

Analizuojant suteiktu prekinių kredito pokyti, lyginant 2010 m. su 2007 m., išryškèja neigiama tendencija, t.y. $2010 \mathrm{~m}$. prekinio kreditavimo apimtys sumažejo beveik visose analizuojamose ES šalyse, išskyrus Švediją (teigiamas 25,3 proc. pokytis), Malta ir Suomija (atitinkamai 9,2 ir 4 proc.). 2 paveiksle pateikti patenkintu prekinio kreditavimo prašymų duomenys, išreikšti procentais. Pateikti duomenys atspindi ne bendrą prekybos apimčiu sumažèjimą, o po ekonominio nuosmukio išlikusias atsargesnio prekinio kreditavimo tendencijas.

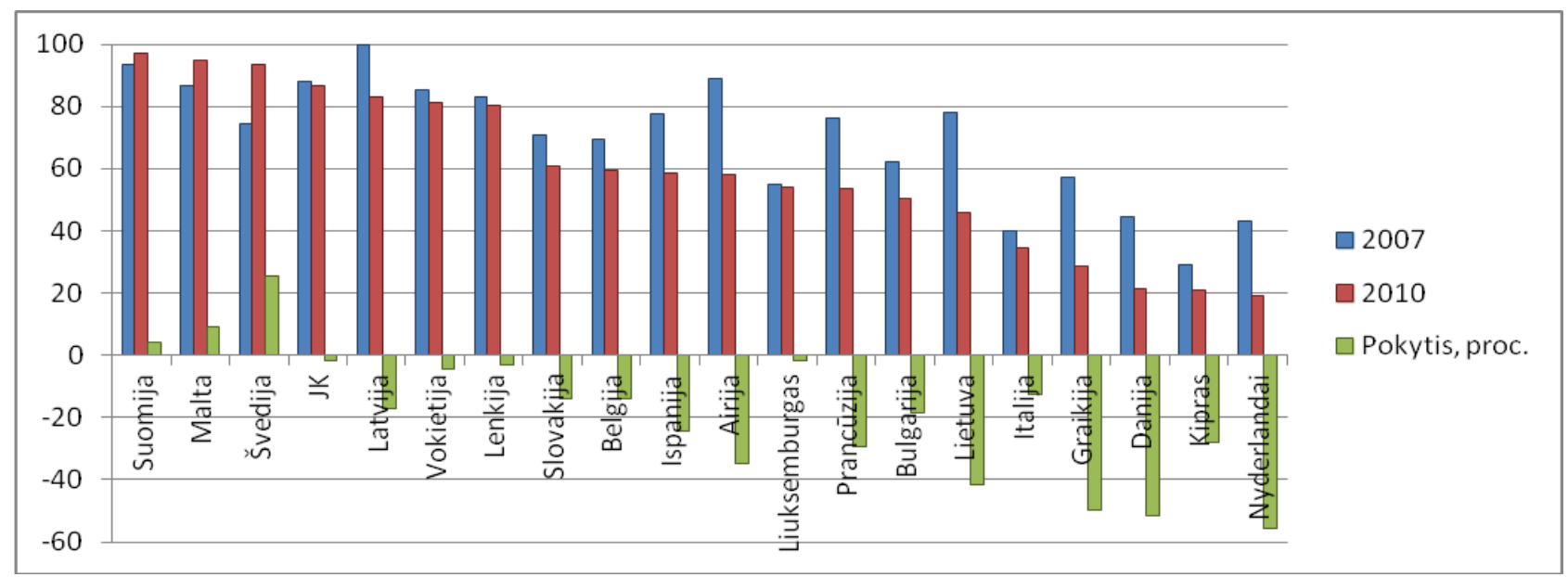

2 pav. Suteikti prekiniai kreditai kai kuriose ES šalyse (visiems ekonomikos sektoriams, išskyrus finansu ir draudimo), proc. (Eurostat, 2012)

Prekinio kreditavimo apimčių neigiamas pokytis parodo sumažejusį prekybos partnerių norą kredituoti savo pirkejjus, tai gali būti susiję ne tik su padidèjusia pirkèjų mokumo rizika bei neapibréžta ekonomine situacija kai kuriose ES bei euro problemomis, bet ir su padidejusiomis pačių eksportuotojų finansavimo išlaidomis bei bankų politika ir griežtomis imonių kreditavimo sąlygomis. Kita vertus, galima daryti prielaida, kad tų šalių, kuriose prekinio kreditavimo apimtys padidejo, ekonomika verslo partneriai labiau pasitikejjo.

Palyginus suteiktu prekinių kreditu apimtis bendrai ekonomikoje su atitinkamai duomenimis apdirbamosios pramonès sektoriuje, nustatyta, kad gaunamų prekinių kreditų apimtys - palyginus su visa ekonomika - apdirbamajai pramonei sumažejo: vidutiniškai bendro prekinio kreditavimas analizuojamose šalyse sumažejo 19,4 procento, o apdirbamajai pramonei - atitinkamai 20,8 procento. Ypatingas kreditoriu pasitikejjimas buvo išreikštas Švedijos apdirbamosios pramonès sektoriumi, taip pat pramonès prekinis kreditavimas didejo Vokietijoje bei Jungtinèje Karalysteje. Šiose trijose šalyse apdirbamosios pramonès kreditavimas išaugo atitinkamai 119,8 proc., 13,5 proc. ir 3,9 proc. (3 pav.). Tačiau daugumoje analizuojamu 
ES šaliu prekinis kreditavimas apdirbamojoje pramonëje buvo mažesnis nei prekinis kreditavimas apskritai ekonomikoje. Itin ryškus prekinių kreditų sumažejimas pastebimas Danijoje (2010 m. suteikta 73,4 proc. mažiau prekiniu kreditu nei $2007 \mathrm{~m}$.), Graikijoje (62,8 proc.), Nyderlanduose (50,3 proc.), Ispanijoje (46,3 proc.), Airijoje (46,2 proc.), Liuksemburge (44,5 proc.), Slovakijoje (40,9 proc.), Lietuvoje (40,2 proc.).

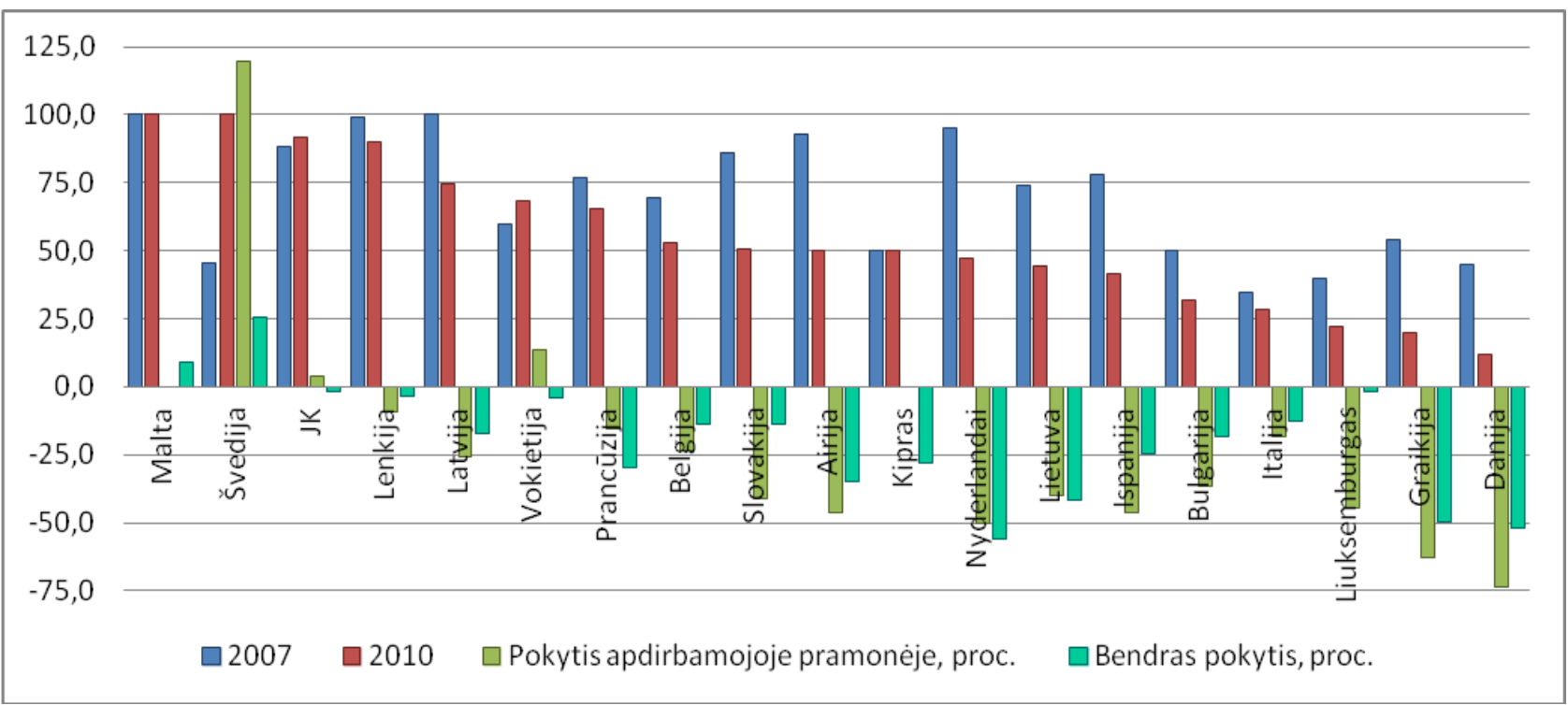

3 pav. Suteikti prekiniai kreditai apdirbamajai pramonei kai kuriose ES šalyse, proc. (Eurostat, 2012)

Toks prekinio kreditavimo sumažejjimas rodo situacijos netikrumą ir itemptą finansinę padèti apdirbamosios pramonès sektoriuje, palyginus su bendra ekonomine situacija konkrečioje šalyje. Kaip pavyzdi galima paminèti tokias išvystytos apdirbamosios pramonès šalis kaip Slovakiją ar Ispaniją kur apdirbamosios pramonės kreditavimas buvo žymiai mažesnis nei prekinis kreditavimas apskritai visoje ekonomikoje (atitinkamai 26,9 ir 21,8 proc. mažiau gautų prekinių kreditu).

\section{Išvados}

Šiuolaikinė tarptautinė prekyba neįsivaizduojama be prekinio kreditavimo, nepaisant ekonominiu sąlygų, taigi ir prekinio kredito reikšmė tarptautinei prekybai išlieka didelè nepaisant to, ar ekonomika yra nuosmukyje, ar ne. Kita vertus, kinta tokių kreditinių santykiu teikiama nauda eksportuotojas ir importuotojams, o svarbiausiu tampa finansinis kreditavimo motyvas. Importuotojams prekinis kreditas svarbus finansavimo šaltinis, ypač tokiu laikotarpiu, kai bankai sugriežtina kreditavimo sąlygas. Kita vertus, esant itemptai ekonominei situacijai, eksportuotojai turi prisiimti kreditavimo riziką, o susitraukus pasaulinei rinkai ir esant aštriai konkurencijai, prekinio kredito palūkanos ne tik dideja, o priešingai - sumažèjo. Taigi, eksportuotojai, atlikdami finansavimo funkciją, konkuruoja rinkoje ne tik eksportuojamais produktais, bet ir teikiama finansine nauda importuotojui.

Atlikta analizė leidžia daryti išvadą, kad užsienio partneriai $2010 \mathrm{~m}$. ES rinkomis pasitiki mažiau, nei 2007 m., nes vidutiniai prekinio kreditavimo pokyčiai bendrai ekonomikoje yra neigiami. Iš visu analizuotu šaliu labiausiai pasitikima Švedijos verslu, kur prekinio kreditavimo pokyčiai yra teigiami, ypatingai apdirbamosios pramonès sektoriuje.

\section{Literatūra}

1. Banham, R. (2000). Insurers Build Export Credit Share. Treasury \& Risk Management, 10, 4, 49-51

2. Berlin, M. (2003). Trade Credit: Why Do Production Firms Act as Financial Intermediaries? Business Review, Q3, 21-28.

3. Bruneckiene, J., Paltanaviciene, D. (2012). Measurement of Export Competitiveness of the Baltic States by Composite Index. Inzinerine Ekonomika-Engineering Economics, 23(1), 50-62.

4. Cheng, N.S., Pike, R. (2003). The Trade Credit Decision: Evidence of UK Firms. Managerial and Decision Economics, 24, 419-438.

5. European Commission (2012). Trade. Prieiga: http://europa.eu/pol/comm/index_en.htm. 
6. Eurostat. (2012). Success rate in obtaining other types of finance. Prieiga: http://epp.eurostat.ec.europa.eu/portal/page/portal/statistics/search_database.

7. Giannetti, M., Burkart, M., Ellingsen, T. (2001). What You Sell Is What You Lend? Explaining Trade Credit Contracts. The review of Financial Studies, V.24, No.4, 1261-1294.

8. International Monetary Fund. (2012). World Economic Outlook April 2012: Growth Resuming, Dangers Remain. Prieiga: http://www.imf.org/external/pubs/ft/weo/2012/01/pdf/text.pdf.

9. Mileris, R., \& Boguslauskas, V. (2010). Data Reduction Influence on the Accuracy of Credit Risk Estimation Models. Inzinerine Ekonomika-Engineering Economics, 21(1), 5-11.

10. Ng, C.K., Smith, J.K., Smith, R.L. (1999). Evidence on the Determinants of Credit Terms Used in Interim Trade. Journal of Finance 54(3), 1109-1129.

11. Paul, S.Y. (2007). Trade Credit: Understanding Its Importance. Credit Management, March 2007, 42-45.

12. Pridotkiene, J., \& Dapkus, M. (2011). The Model to Evaluate Risk Factors of Exporter-Provided Trade Credit. Inzinerine Ekonomika-Engineering Economics, 22(5), 477-484.

13. Pridotkienè, J., Snieškienè, G. (2011). Prekinio kredito rizikos formavimosi prielaidos eksporto atveju. Economics \& Management, 280-286.

14. Saboniene, A. (2009). Lithuanian Export Competitiveness: Comparison with other Baltic States. Inzinerine Ekonomika-Engineering Economics(2), 49-57.

15. Summers, B., Wilson, N. (2003). Trade Credit and Customer Relationships. Managerial and Decision Economics 24, 439-455.

16. Paul, S., Wilson, N. (2007). The Determinants of Trade Credit Demand: Survey Evidence and Empirical Analysis. Journal of Accounting - Business \& M0anagement 14, 96-116. 